تشوت ليندا مر هبني

\title{
جبر الأحاديث المرسلة بتعدد طرق أحاديث كتاب فضائل القرآن في مصنف عبل الرزاق نموذجا كناب
}

\author{
تثوت لينذا مر هيني \\ Jurusan Pendidikan Agama Islam Sekolah Tinggi Agama Islam Negeri Gajah Putih Takengon \\ Jl Aman Dimot, No. 10 Takengon, Aceh Tengah Aceh \\ Email: cutlindamarheni@gmail.com
}

\begin{abstract}
The purpose of this research is to support mursal hadis with syawāhid and mutāba 'ât. Al-jabr and altarqiyah defined as supporting a weak hadis with the narrations from other ways that have a better verdicts. The hadis scholars agree that weak hadis which has an unsevere weaknesses such as sü' hifz or broken chain like mursal which has a missing narrator at the end of the chain after sahabah or no information available about the trustworthiness of narrators can be raised to the level of hasan li ghairih. And the reason of choosing kitab Fadāil Qurān as the object of this study is because many hadis related to this chapter are weak, especially from the compilation of Abd Razzaq who did not stipulate the authenticity for his book. This research will present syawāhid and mutāba'ät for hadis mursal starting with the same mursal narrations for which will strengthen each other if the chains are authentic and come from other ways of mursil. This paper will also give the connected chain of the hadis narrated through the way of mursil, in order to know who was missing from the chain whether it is a companion or companion with a successor as well as other syawähid from other narrator or even other companion. With the support of this syawāhid and mutāba 'àt will help to decide which mursal hadis can be upgraded or remain mursal because the weaknesses is strong or the supports are not valid.
\end{abstract}

Keywords: Mursal, Mușannif 'Abd al-Razzāq, Syawāhid

\begin{abstract}
Abstrak
Tujuan dari studi ini adalah untuk menguatkan hadis mursal dengan syawāhid dan mutāba'āt. Yang dimaksud dengan al-jabr dan al-tarqiyah di sini adalah mendatangkan jalur periwayatan lain untuk hadis mursal yang hukumnya lebih kuat. Para ulama hadis sepakat bahwa hadis dhaif, yang kelemahannya ringan, seperti su' ' hifz perawi, atau terputusnya sanad, seperti hadis mursal yang hilang seorang perawi sesudah sahabat, atau hadis yang diriwayatkan oleh perawi yang tidak diketahui 'adālahnya dapat di naikkan derajatnya menjadi hasan li ghairihi. Alasan memilih kitab Fad̄āil Qurān adalah karena banyak sekali hadis-hadis yang berhubungan dengan topik tersebut adalah dhaif, terlebih lagi dari kumpulan hadis Musannif 'Abd al-Razzāq yang tidak mensyaratkan keshahihan dalam hadis- hadis kompilasinya. Dalam tulisan ini, penulis akan mendatangkan jalur periwayatan lain dari hadis mursal yang mursal juga dari jalur lain. Hal ini karena, hadis mursal sendiri saling menguatkan jika diriwayatkan dari jalur selain jalur mursil. Penulis juga akan mendatangkan riwayat yang bersambung dari jalur mursil, guna mengetahui perawi yang jatuh sesudah sahabat, adakah ia sahabat saja, atau sahabat dan tabiin. Sebagaimana penulis juga akan mendatangkan jalur periwayatan lain yang bersambung atau periwayatan sahabat lain. Dengan bantuan syawāhid dan mutāba 'àt ini, penulis akan menentukan mana saja hadis yang dapat naik derajat kepada hasan li ghairihi dan yang tetap mursal, karena terlalu parah kedhaifannya atau ketidak tersediaan syawāhid yang kuat.
\end{abstract}

Kata Kunci: Mursal, Mușannif 'Abd al-Razzāq, Syawāhid 
الصحيحة والضعيفة والموصولة والمنقطعة، فنحتاج قبل الاعتماد عليه إلى دراسته. إن المصنف وإن قلت شهرته عن كتب الصحاح بين المحدثين المتقدمين، 3 وقلت دراسته من جانب الشرح أو التعليق أو التخريج، إلا أنه زاد الاهتمام به الآن من بين طلاب العلم، خاصة المتخصصين في الحديث وعلومه، بالتحقيق أو الاختصار أو الفهرسة أو دراسة أحاديثها بشكل المقالات أو الرسائل الجامعية. وهذا البحث بعنوان جبر الأحاديث المرسلة بتعدد الطرق أحاديث كتاب فضائل القرن في مصنف عبد الرزاق نموذجا، سوف تتناول الباحثة فيه الأحاديث المرسلة من الكتاب المذكور بالدراسة، بغية الوصول إلى حكمها، وذلك بسبر أحاديثها ودراسة سندها ومتنها. المشكلة التي أرادت الباحثة معالجتها تتمثل في سعة شرط مصنِف المصنف، وهو كما وصفه ملا علي القاري:

2 محمد أبو الليث الخير آبادي، " مصنف الإمام عبد

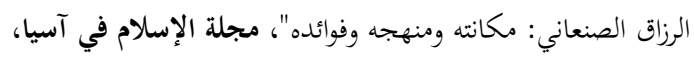

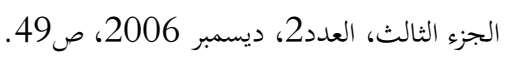

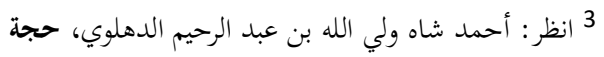
الله البالغة، (بيروت: دار الكتب العلمية، د. ط، 2001 م)، 251.

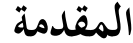

ومن أوائل من صنف في الحديث الإمام الحافظ أبو بكر عبد الرزاق بن همام بن نافع الحميري (ت 211هـ)، رحمه الله تعالى، فقد بند قام بتصنيف كتاب عظيم القدر جليل النفع، اشتهر بـ مصنف عبد الرزاق، يحتوي على أحاديث رسول الله بـ التابعين وأتباعهم بأسانيدها، كما هو معهود من ونه تعريف "المصنفات" والمعروف من حالها، فهي كما عرفها الكتاّني في سياق الكتب المصنفة في الحديث. والمصنف الذي نحن بصدد دراسته والذي وصفه الحافظ الذهبي بـ "خزانة علم،" "1 يمثل موسوعة فقهية ثرية، لا يستغني عنه باحث عن أدلة الأحكام، حيث جمع فيه مصنفه كل ما انتهى إليه من أحاديث الأحكام وآثارها، واستقصى فيه المسائل الفقهية بكامل جوانبها، أصولها وفروعها، ولا يترك ما يتعلق بها من أحاديث أو آثار وهو عنده إلا أن يذكره، 2 وذلك بغض النظر عن صحة الأحاديث أو أو أول رفعها أو وصلها، فتشمل الأحاديث فيه

$$
\begin{aligned}
& 1 \text { أبو عبد الله محمد بن أحمد بن عثمان الذهبي، ميزان }
\end{aligned}
$$

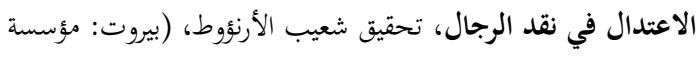

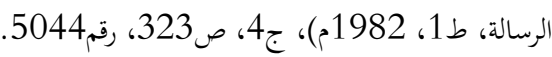


2. سقط من سنده كالمعلق والمرسل والمعضل والمنقطع والمدلس والمرسل<smiles>[V]=[As]</smiles>

3. جهالة عدالته كحديث مجهول العين

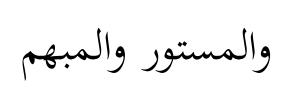

عاضد صالح لترقية الاحاديث الضعيفة هو تعدد الطرق:مما اتفق المحدثون عليه دون استثناء أن العمدة في باب ترقية الأحاديث الضعيفة هو تعدد الطرق، لا غير. لأنه إذا تتابع عدة أشخاص واجتمعوا على نقل الخبر، فمن الطبيعي المشهور أن يقويه هذا التتابع والاجتماع ويزيد احتمال صدقه ويرفع درجته من الأدنى إلى الأعلى.6 أما تعريف المرسل الذي تسير عليه الباحثة في جمع مراسيل المصنف، هو ما اشتهر عند المحدثين: ما سقط من آخره من بعد التابعي. وصورته عند المحدثين أن يقول

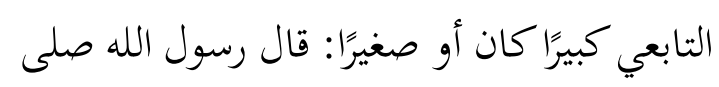
الله عليه وسلم كذا، أو فعل كذا، أو فعل بحضرته كذا ولم ينكر، 7 أو أن يروي قصة لم كلم كلما،

$$
\begin{aligned}
& 6 \text { الخير آبادي، علوم الحديث أصيلها ومعاصرها، كوالا }
\end{aligned}
$$

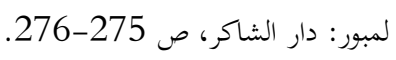

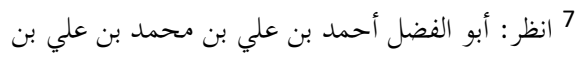

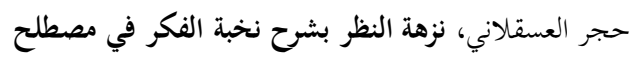

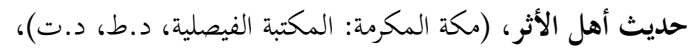

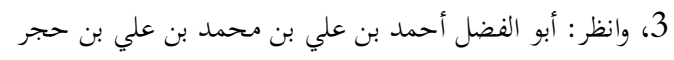

لا يشترط فيه وأمثاله من السنن

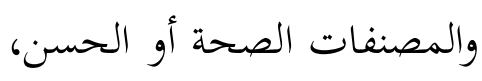
فيخشى إن يقدم أحد على أولى الحنى

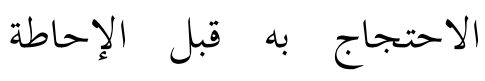
والفحص، فيكون كحاطب ليل، الدجاج

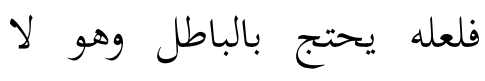
يشعر. 4

ولا يعني ذلك جواز إهمال هذا الكتاب والتقليل من شأنه، فهو بمثابة الديوان العظيم والبحر الزاخر من الأحاديث، استقى منه العلية من أئمة الحديث كأصحاب الكتب الستة

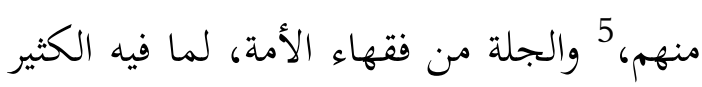
من الأحاديث الصحيحة أو الضعيفة التي تنجبر، خاصة مراسيل التابعين التي لها ميزة خاصة من بين الأحاديث المنقطعة الإسناد، وذلك لأن الساقط من الإسناد غالبا صحابي، وقد ثبت تعديلهم كلهم بالكتاب والسنة.

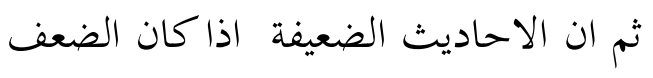

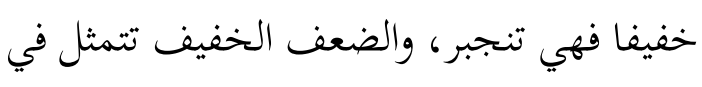
الأسباب الاتية: 1. سوء الحفظ كالحديث المختلط لائه

$$
\begin{aligned}
& 4 \text { علي بن سلطان محمد نور الدين الملا الهروي القاري، }
\end{aligned}
$$

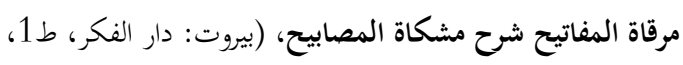

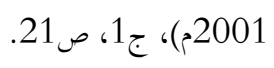

$$
\begin{aligned}
& 5 \text { انظر: الخير آبادي، "مصنف الإمام عبد الرزاق } \\
& \text { الصنعاني،" المرجع السابق، } 41 \text { الخير آدي، "معن }
\end{aligned}
$$


جبر الأحاديث المرسلة بتعلد طرق أحاديث كتاب فضائل القرآن في مصنف عبد الرزاق نموذجا

يحضرها، 8 أو أن يقول "أمرنا بكذا،" "أو "نهينا التابعين. وهذا الرأي الراجح عند السيوطي،

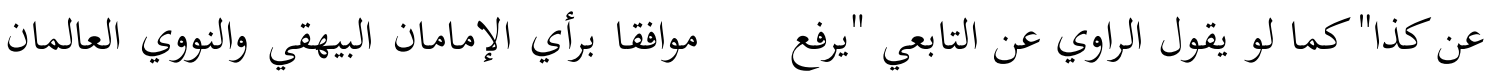
الحديث،" أو "يبلغ به،" أو "ينميه"-ــيرفعه بنصوص الشافعي، لأنه قد وجد العلماء أن في إلى النبي - أو "رواية رفع،"10 أو "يسنده،" أو مراسيله ما ليس مسندا، خلافا لمن قال كذلك. وزاد الإمام النووي: لم يعتمد الشافعي في 11 " مؤثره. ترجيحه تحريم بيع الحيوان باللحم بمرسل ابن المسيب وحده، بل لما انضم إليه قول الصحابة والتابعين. 12أما مراسيل الصحابي 13 فحكمها حكم المتصل، لا خلاف فيه، 14 فلا داعي إذن أن تلحقها الباحثة في هذا البحث.

\footnotetext{
11 انظر: زين الدين أبو يحي زكريا بن محمد زكريا السنيكي، البراف

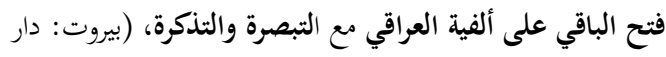

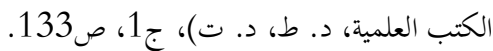

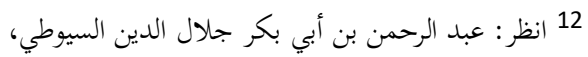

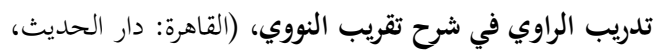

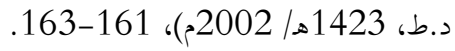
13 وهو "ما أخبر به الصحابي من قول أو فعل رسول الله

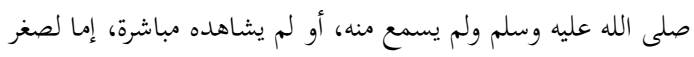

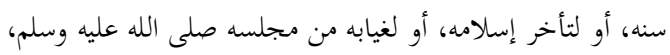

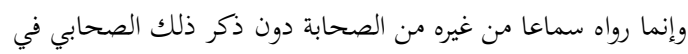

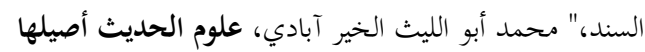

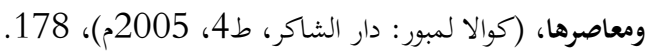
14 قال العراقي: "إن المحدثين وإن ذكروا مراسيل الصحابة،

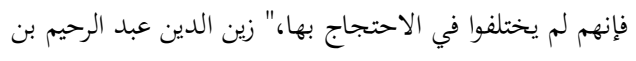

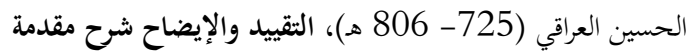

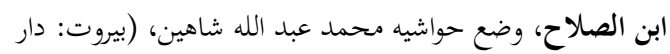

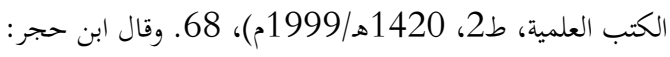
"وكم في الصحيح من مرسل صحابي، وقد اتفق الأئمة قاطبة على الى العان

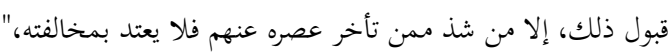

العسقلاني النكت على كتاب ابن الصلاح، (الرياض: دار الراية،

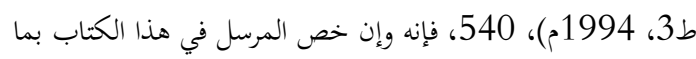

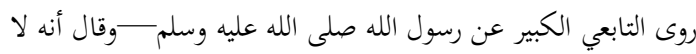

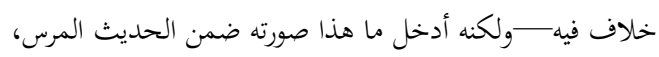
وانظر أيضا: محمود الطحان، تيسير مصطلح الحديث، (الرياض:

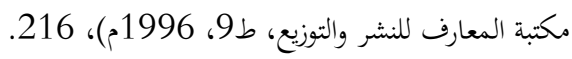

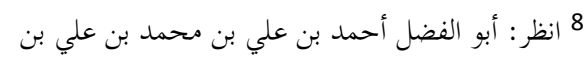

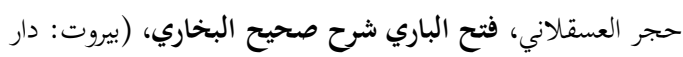

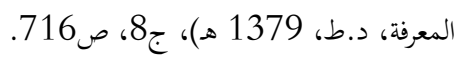
9 استنبطه العراقي من كلام الغزالي في المستصفى، وأن هذا هذا اللفظ يحتمل الوقف والإرسال ولم يصرح بالترجيح، وقال العراقي:

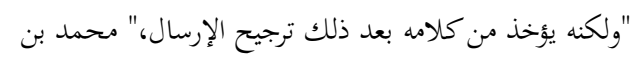
الحسين العراقي الحسيني، شرح ألفية العراقي المسماة بالتبصرة

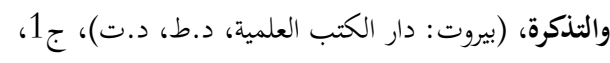

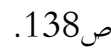
10 انظر: العراقي، المرجع السابق، ج1، ص133. وانظر

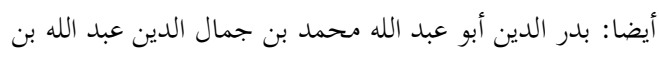
بهادر الزركشي، النكت على مقدمة ابن الصلاح، (الرياض: أضواء

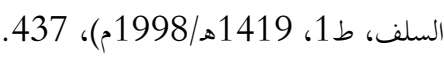


نتيجة البحث: الأحاديث الضعيفة في فضائل

القرآن وجبرها بتعدد الطرق: باب كم في القرآن من سجدة

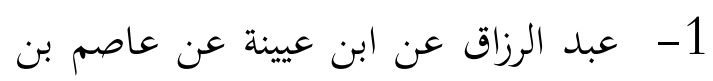
سليمان عن بكر بن عبد الله المزني أن رجلا أتى النبي صلى الله عليه وسلم فقال: يا رسول الله رأيت كأن رجلا يكتب القرآن وشجرة

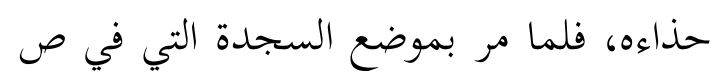
سجدت، وقالت: اللهم أحدث لي بها شكرا وأعظم بها أجرا واحطط بها وزرا، فقال النبي

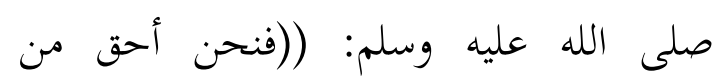

شجرة)). رجاله:

ابن عيينة: هو سفيان، ثقة فقيه إمام، تقدم.

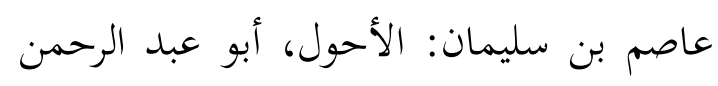
البصري، ثقة، من الرابعة، مات بعد سنة أربعين

ومائة هـ.

بكر بن عبد الله المزني: ثقة ثبت جليل، من الثالثة، مات سنة ست ومائة هـ. 16

تخريجل:

تفرد عبد الرزاق بإخراجه مرسلا، وقد رواه الحاكم موصولا ومختصرا عن طريق حماد بن

\footnotetext{
15 ابن حجر،(1975م). تقريب التهذيب، حققه وعلقه

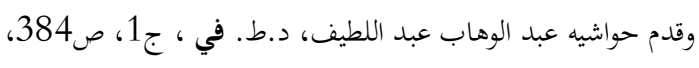
رقم9. - (20)

$$
16 \text { ابن حجر، التقريب، ج1، ص106، رقم117. }
$$
}

منهجية البحث:

سوف تسلك الباحثة في هذا البحث المناهج

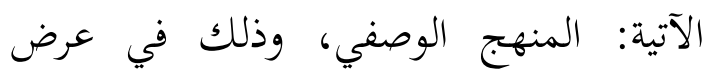
المعلومات مصنف عبد الرزاق ومعرفة الحديث ونيث المرسل وحكمه و المنهج التحليلي والنقدي، وذلك في سبر مراسيل مصنف عبد الرزاق

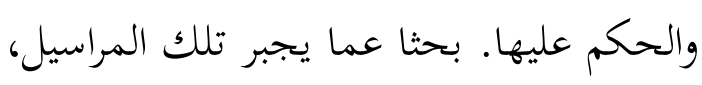
سوف تأتي الباحثة بمتابعاتها وشواهدها، فتبدأ بمتابعات مرسلة أولا عن شيخ عبد الرزاق أو ما

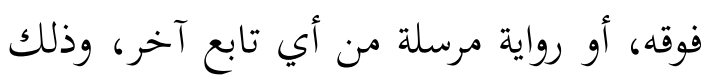
لمعرفة هل تفرد عبد الرزاق بروايتها مرسلة أم له

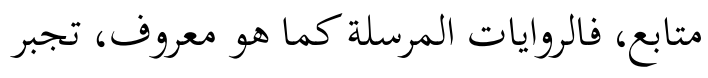
بعضها بعضا إن كانت صحيحة الإسناد،

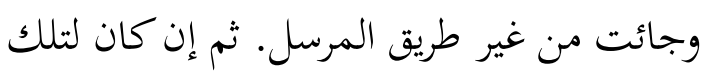
المراسيل روايات موصولة عن طريق المرسل

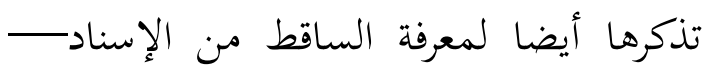

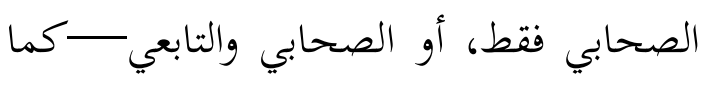

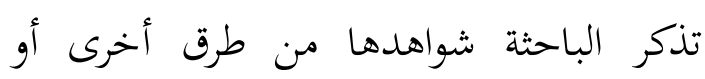

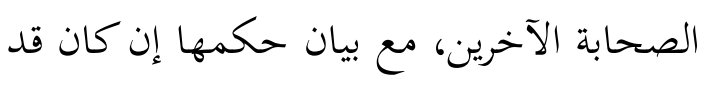

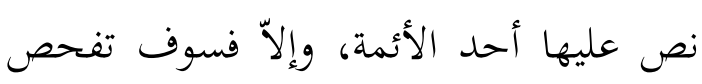

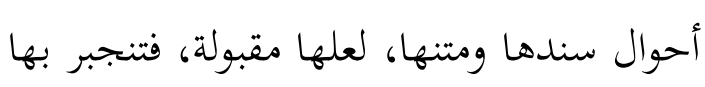
مراسيل المصنف. ابن حجر، هدي الساري مقدمة فتح الباري، (بيروت: دار الكتب

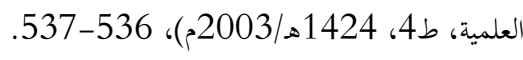


سلمة وأحمد من طريق يزيد بن زريع، والبيهقي اللهصلى الله عليه وسلم فقال: يا رسول الله إني عن طريق هشيم والثلاثة عن حميد أن أبا سعيد رأيت في هذه الليلة فيما يرى النائم كأني أصلي

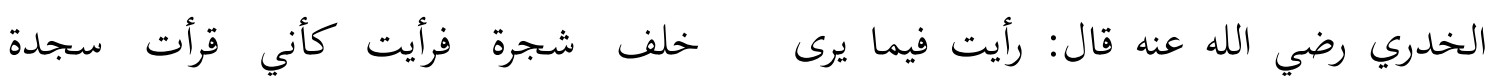

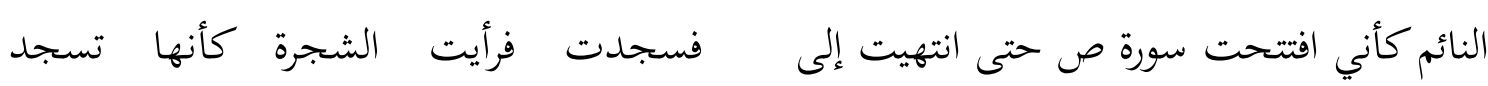
السجدة فسجدت الدواة والقلم وما حوله بسجودي فسمعتها وهي ساجدة، وهي تقول:

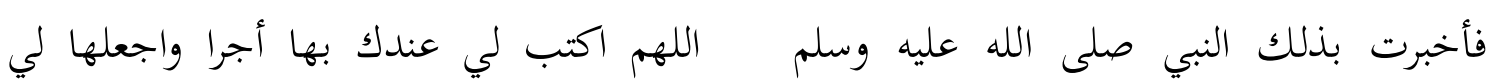
فسجد فيها، وهذا لفظ الحاكم، وطرف حديث عندك عند ذخرا وضع عني بها وزرا واقبلها مني كما

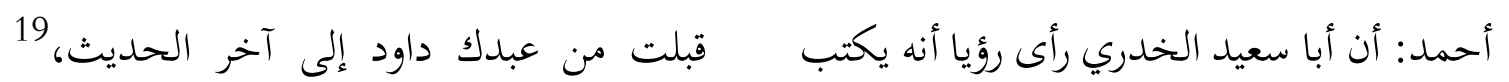

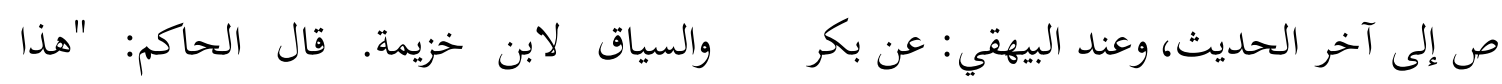

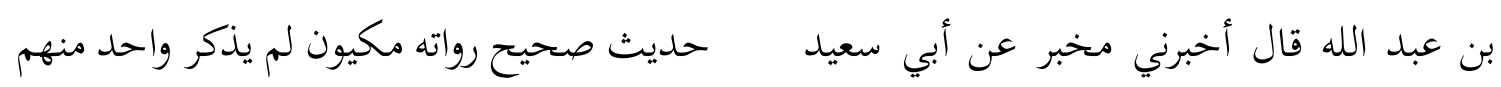

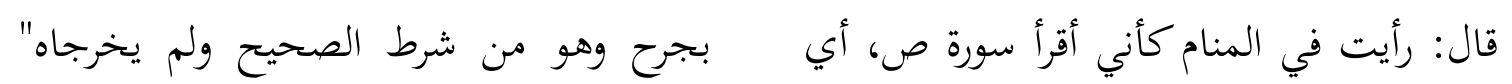

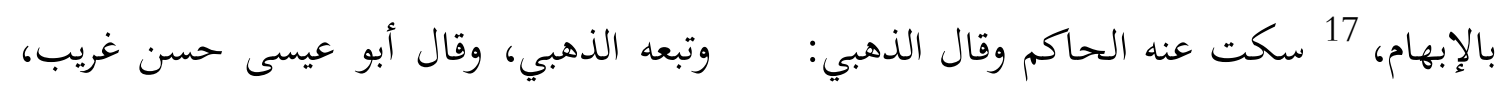

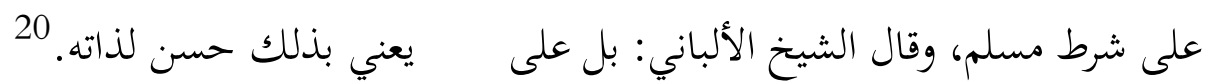

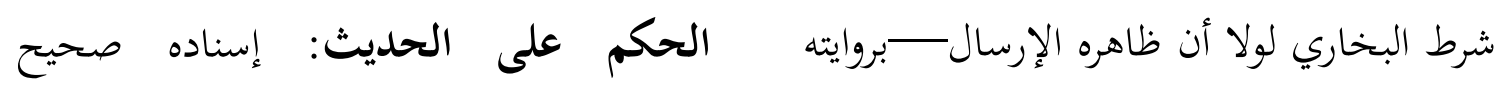
والحديث مرسل، فمتابعه وشاهده الصحيح زاده مأنأنا. 18

$$
\text { وله شاهد أخرجه ابن ماجه والترمذي قوة، فيرتقي إلى الحسن لغيره. }
$$

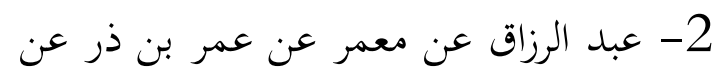

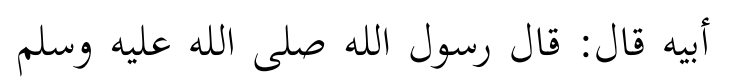
وابن خزيمة والحاكم والطبراني بطرق عن محمد بن يزيد بن خنيس قال قال لي ابن جريج قال

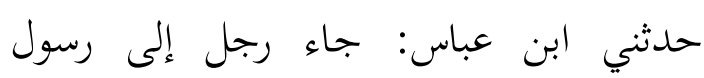

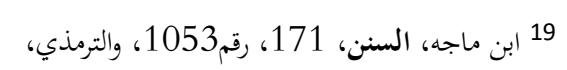

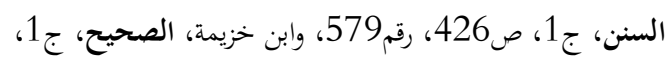

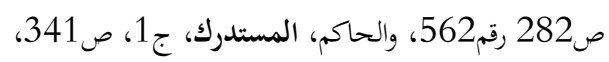

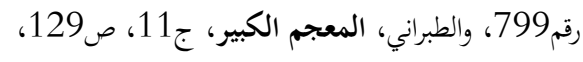
رقم1262 20 انظر: الألباني، السلسلة الضعيفة، ج2، ص185، في رئ

$$
\text { تخريج حديث رقم765. }
$$
}

17

$$
\begin{aligned}
& \text { الصحيحين، تحقيق مصطفى عبد القادر عطا. بيروت: }
\end{aligned}
$$

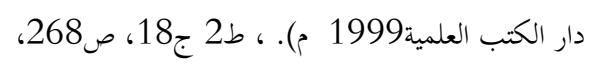

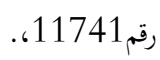

$$
\begin{aligned}
& \text { ج2، ص433، 450، رقم3750، 3616، والبيهقي، السن، } \\
& \text { ج2، ص453، رقم3750، صن. }
\end{aligned}
$$

$$
18 \text { الألباني، السلسلة الصحيحة، ج6، ص209، }
$$


بنحوه، قال: "وليس بالقوي،" وهو الذي أخرجه النسائي عن طريق حجاج بن محمد والطبراني عن محمد بن الحسن والدارقطني عن عبد الله بن بزيع، والثلاثة عن عمر بن ذر، وعندهم:

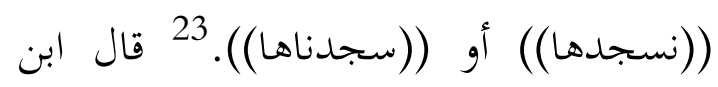
حجر في الدراية: "رواه النسائي، ورواته ثقات."24 فكأن إشارة البيهقي بقوله "ليس بالقوي"25 تتجه إلى رواية الدارقطني عن عبد الله بن بزيع الأنصاري، "قال فيه ابن عدي: ليس ليس ردئ عندي ممن يحتج به، قال الدارقطني: لين

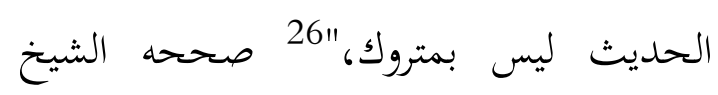

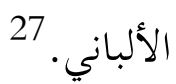
الحكم على الحديث: سند الحديث صحيح، ولكنه ضعيف بالإرسال ويرتقي إلى الحسن لغيره بمتابعه وشاهده.

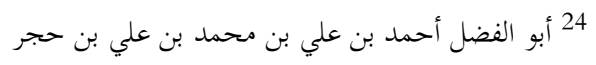

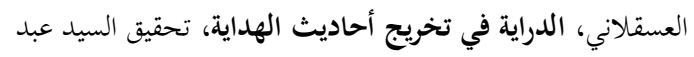

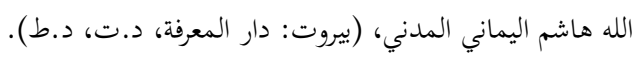

$$
\begin{aligned}
& 25 \text { قال الشيخ الألباني: وهو خلاف قوله: "ليس بقوي،" }
\end{aligned}
$$

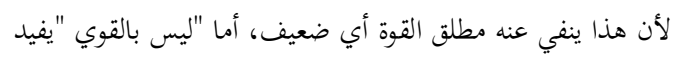

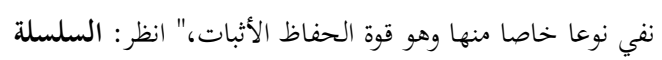

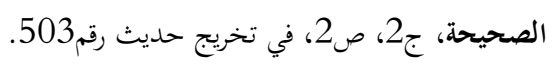

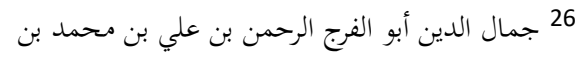

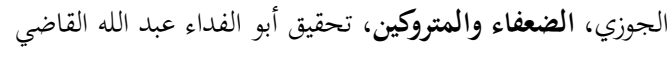

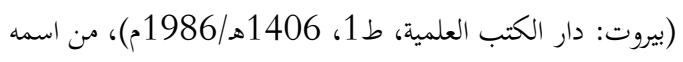

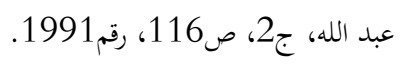

$$
\begin{aligned}
& 27 \text { الألباني، صحيح وضعيف سنن النسائي، ج3، 101، رقان. }
\end{aligned}
$$

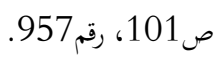

في سجدة ص: ((سجدها داود توبة، وسجدتها شكرا()

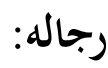
معمر: هو ابن راشد الأزدي، ثقة ثبت، تقدم. عمر بن ذر: ابن عبد الله بن زرارة الهمداني المرهبي، أبو ذر الكوفي، ثقة، رمى بالإرجاء، من السادسة، مات سنة ثلاث وخمسين ومائة هـ، وقيل غير ذلك. 21 أبوه: هو ذر بن عبد الله المرهبي، ثقة، من السادسة، رمى بالإرجاء. 22

\section{تخرجه: - ت تخ}

أخرجه البيهقي عن طريق الشافعي عن سفيان عن عمر بن ذر عن أبيه مرسلا بنحوه، وقال: "هذا المحفوظ مرسل،" وروى من طريق آخر عن عمر بن ذر عن أبيه عن سعيد بن جبير عن ابن عباس عن النبي صلى الله عليه وسلم مرفوعا

$$
\begin{aligned}
& 21 \text { ابن حجر، التقريب، ج2، ص55، رقم420. }
\end{aligned}
$$

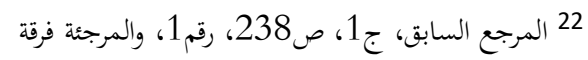

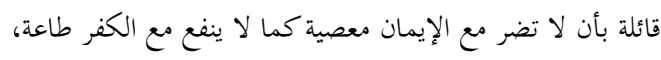

$$
\begin{aligned}
& \text { انظر: اللواء حسن صادق، جزور الفتنة في الفرق الإسلامية، }
\end{aligned}
$$

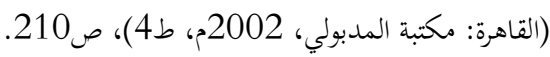

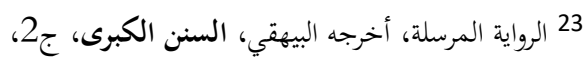

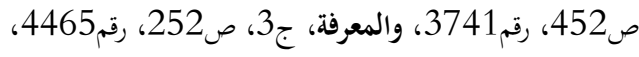

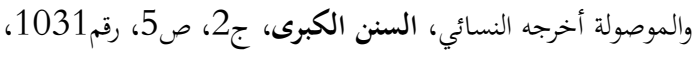

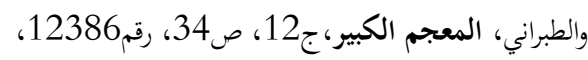

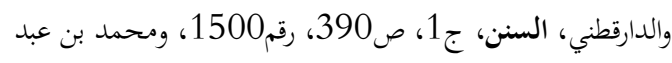

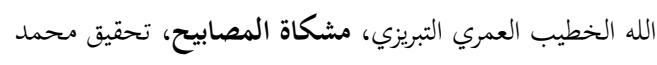

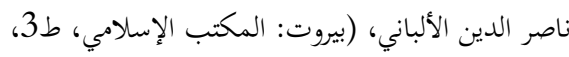

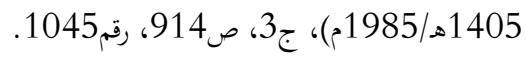


جبر الأحاديث المرسلة بتعلد طرق أحاديث كتاب فضائل القرآن في مصنف عبد الرزق نموذجا

3- عبد الرزاق عمن سمع عكرمة يحدث قال: "ليس بشيء،" وقال النسائي: "ليس بالقوي،"

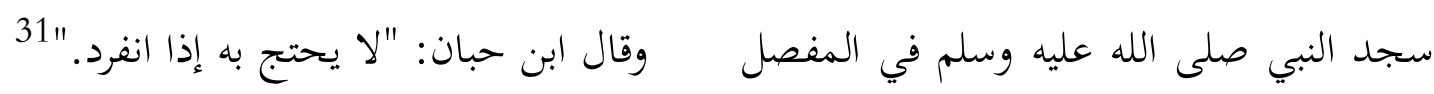

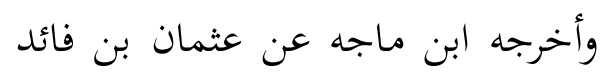
إذا كان في مكة.

عن عاصم بن رجاء بن حيوة عن المهدي بن رجاله: عبد الرحمن حدثتني عمتي أم الدرداء قالت رئ بن حدثني أبو الدرداء: أنه سجد مع رسول الله صلى الله عليه وسلم إحدى عشر سجدة ليس فيها من المفصل شيء. 32 وعثمان بن فائد قال فيه ابن حبان: "يأتي بالمعضلات لاتئ لا يجوز الاحتجاج به. "33

الحكم على الحديث: الحديث ضعيف بالإبهام والإرسال، له شواهد من مرويات الرواة الضعفاء، لا ينجبر بمثلها هذا المرسل. باب سجود الرجل شكرا 4- عبد الرزاق عن الثوري عن جابر عن محمد بن علي قال: مر رسول الله صلى الله عليه وسلم

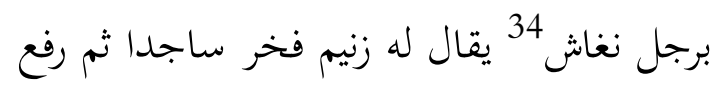
رأسه فقال: ((سل الله العافية)). رجاله:

\footnotetext{
32 ابن ماجه، السنن، 172، رقم1056. 33 ابن الجوزي، الضعفاء والمتروكين، ج2، صند، ص172، 171،

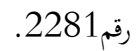
34 النغاش والنغاشي: القصير أقصر ما يكون، الضعيف

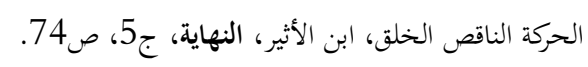
عكرمة: هو ابن عبد الله مولى ابن عباس، أصله بربري، ثقة ثبت، عالم بالتفسير، من الثالثة، مات سنة سبع ومائة هـ. 28 تخريجه: هكذا أخرجه عبد الرزاق، وأخرجه أبو داود (وعن طريقه البيهقي) وابن خزيمة عن أبي قدامة-الحارث بن عبيد الأيادي - اوعن مطر الوراق عن عكرمة عن ابن عباس، موصولا أن النبي صلى الله عليه وسلم لم يسجد في شيئ من المفصل منذ تحول إلى المدينة، 29 قال الذهبي: "وهذا منكر، فقد صح أن أبا هريرة سجد مع النبي صلى الله عليه وسلم فيه لِّفِإذًا

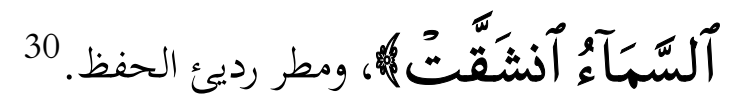
أما أبو قدامة، كثر أقوال الأئمة في تضعيفه، قال أحمد: "هو مضطرب الحديث،" وقال يحيى:

$$
\begin{aligned}
& \text { 28 ابن حجر، التقريب، ج2، ص30، رقم277. }
\end{aligned}
$$

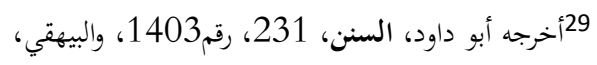

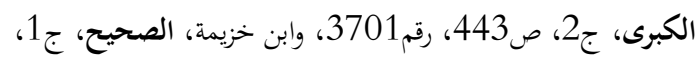

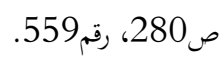

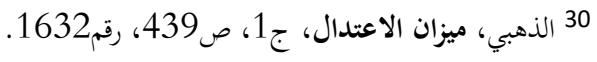

$$
\begin{aligned}
& 31 \text { ابن الجوزي، الضعفاء والمتروكين، ج1، صئ، ص182، صنان، }
\end{aligned}
$$


زمانة فسجد وقال البيهقي: ويقال هذا عفرجة السلمي لا يرون له صحبة فيكون مرسلا. وروى الطبراني في الأوسط عن طريق محمد بن موسى قال ثنا داود بن رشيد به بنحوه، وقال: "لم يرو هذا الحديث عن مسعر إلا حفص بن غياث، تفرد به داود بن رشيد." قال الهيثمي: رواه الطبراني في الأوسط وفيه محمد بن عبد الله

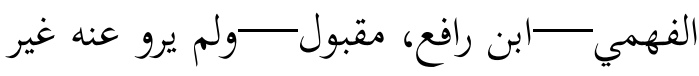
مسعر، 37 أما بقية رواته فثقات. 38

2. ما رواه ابن حبان في المجروحين عن يوسف بن محمد بن المنكدر عن أبيه عن جابر بن عبد الله قال: كان رسول الله صلى الله عليه وسلم إذا انتبه من منامه خر ساجدا وإذا رأى القرد خر ساجدا وإذا رأى الرجل مغبر الخلق خر ساجدا، شكر الله، وقال: "يوسف يروى عن أبيه ما ليس من حديثه من المناكير التى لا يشك عوام أصحاب الحديث أنها مقلوبة، وكان يوسف شيخا صالحا ممن غلب عليه الصالح حتى غفل من الحفظ والإتقان، فكان يأتي بالشئ على التوهم، فبطل الاحتجاج

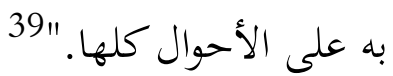

\footnotetext{
ج2، ص189، رقم465، مسعر بن كدام: ثقة ثبت، نفس المرجع،

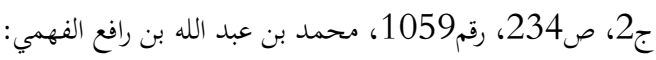

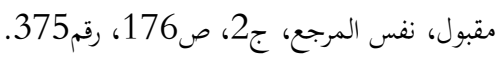

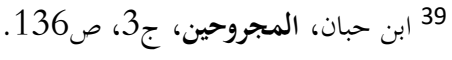

الثوري: هو سفيان بن سعيد بن مسروق، ثقة حافظ، تقدم. جابر: هو ابن يزيد بن الحارث الجعفي، أبو عبد الله الكوفي، ضعيف رافضي، من الخامسة، مات سنة سبع وعشرين ومائة هـ، وقيل سنة اثنتين وأربعين. محمد بن علي: هو ابن الحسين بن علي بن أبي طالب، ثقة، تقدم. تخريجه: أخرجه البيهقي عن سفيان والدارقطني عن طريق هشيم عن جابر عن محمد بن علي مرسال بنحوه. 36 وعند البيهقي: رأى رسول الله صلى الله عليه وسلم رجلا نغاشيا، وعند الدارقطني: رجلا من النغاشين، وبين البيهقي ضعفه بسبين: الانقطاع وضعف جابر ولكن له شاهدان على معناه:

1. ما استشهد به البيهقي عن محمد بن العباس ثنا داود بن رشيد ثنا حفص بن غياث عن مسعر عن محمد بن عبد الله عن عرفجة أن النبي صلى الله عليه وسلم أبصر رجلا به

$$
\begin{aligned}
& 35 \text { ابن حجر، التقريب، ج1، ص123، رقم17. }
\end{aligned}
$$

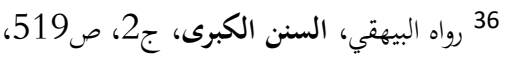

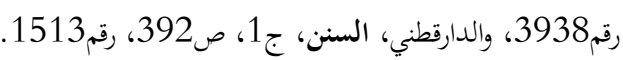

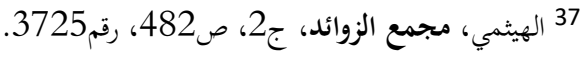

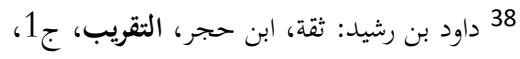

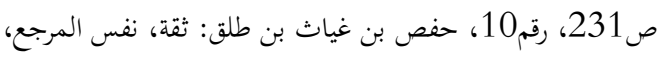




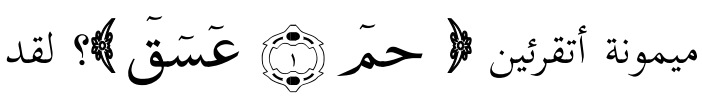
نسيت ما بين أولها إلى آخرها)) فقرأتها فقرأها رسول الله صلى الله عليه وسلم، 41 صحح السيوطي سنده.

الحكم على الحديث: الحديث ضعيف بإرساله ويرتقي إلى الحسن لغيره بموصوله. 5- عبد الززاق عن معمر عن الزهري أن رجلا جاء إلى النبي صلى الله عليه وسلم حين أصبح، فقال إنها كانت معي سورة فذهبت لأقرأها، فلم أقدر عليها، فقال له رجل آخر: وأنا أيضا، كانت معي فما قدرت عليها، فال: ما أدري أرجلان أم ثلاثة، فدخلوا على النبي صلى الله عليه وسلم فأخبروه، قال، فقال: ((إنها رفعت في قرآن رفع).

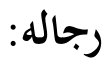

معمر: وهو ابن راشد الأزدي، ثقة ثبت، تقدم. الزهري: محمد بن مسلم بن شهاب، الحافظ، تقدم. تخريجه: - (ت لم تجد الباحثة من أخرجه غير عبد الرزاق.

42 السيوطي، الدر المنثور، ج713، ص128، تفسير

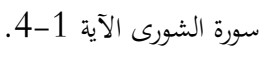

الحكم على الحديث: إسناد الحديث ضعيف لضعف جابر والحديث ضعيف مرسل، ولا نجد له شاهد ما يجبره، ويرتقي من ضعفه. باب تعاهد القرآن ونسيانه 5- عبد الرزاق عن ابن جريج قال: أخبرني جعفر بن محمد أن النبي صلى الله عليه وسلم

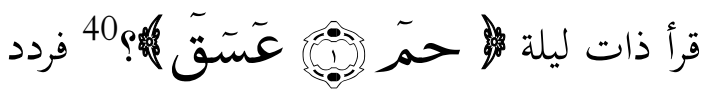

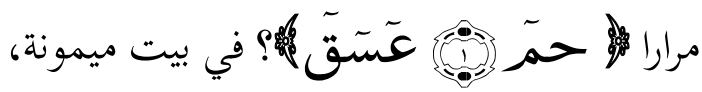

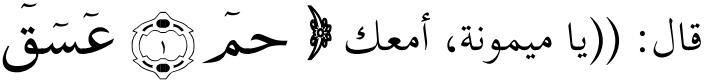
قالت أنسيت ما بين أولها إلى آخرها)).

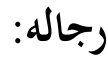
ابن جريج: عبد الملك، ثقة، تقدم. جعفر بن محمد بن الحسين بن علي، صدوق، تقدم. تخريجه: أخرجه الطبراني في الكبير موصولا عن طريق سعيد بن يحيى الأموي ثنا أبي عن ابن جريج عن جعفر بن محمد عن أبيه عن ميمونة قالت: قرأ رسول الله صلى الله عليه وسلم فقال: (يال

$$
40 \text { سورة الشورى، الآية: 1- 20 } 10 \text { الطبراني، المعجم الكبير، ميمونة بنت الحارث، ج24، }
$$

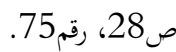


((فاتني الليلة جزئي القرآن))، هذا سياق

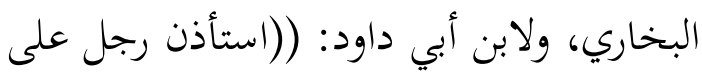
رسول الله صلى الله عليه وسلم وهو بين مكة ولن والمدينة فقال: إنه قد فاتني الليلة جزئي من القرآن، فإني لا أؤثر عليه شيئا))، وللبخاري طريق آخر عن عبد الله بن عبد الرحمن الطائفي عن عثمان بن عبد الله بن أوس عن أبيه عن

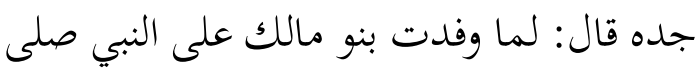
الله عليه وسلم ضرب عليهم قبة، فذكر الحديث. 44 نقول: تفرد به عثمان بن عبد الله بن أوس، قال ابن حجر: مقبول، 45 ومن المعلوم أن هذا المصطلح معناه عند الحافظ: "مقبول، حيث يتابع، وإلا فلين الحديث."46 الحكم على الحديث: رجال الإسناد ثقات ولكن الحديث ضعيف بإرساله، ولا ينجبر لإسبى بشاهده، لأنه أضعف منه. باب تعليم القرآن وفضله 7- عبد الرزاق عن معمر عن ليث عن عبد الرحمن بن سابط قال قال رسول الله صلى الله عليه وسلم: ((البيت الذي يقرأ فيه القرآن يكثر خيره ويوسع على أهله ويحضره الملائكة ويهجره الشياطين، وإن البيت الذي لا يقرأ فيه يضيق على أهله ويقل خيره ويهجره الملائكة
الحكم على الحديث: رجاله ثقات، والحديث مرسل، ولم يرتقي إلى الحسن لغيره لفقدان

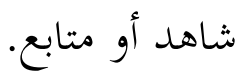
6-عبد الرزاق عن ابن جريج قال: أخبرني محمد بن عباد بن جعفر أن وافدا أتى النبي صلى الله عليه وسلم بمكة، فسألوه أن يخليهم لحاجتهم، فقال: إني فاتني الليلة حزب من

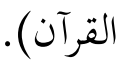

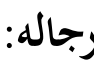
ابن جريج: هو عبد الملك، ثقة، تقدم.

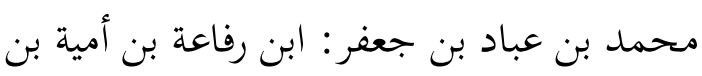

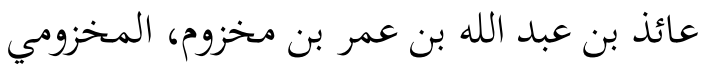
المكي، ثقة، من الثالثة.

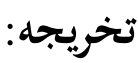

تفرد عبد الرزاق بإخراجه مرسلا، ورواه البخاري في التاريخ وابن أبي داود في المصاحف موصولا عن طريق محمد بن مسلم عن عثمان

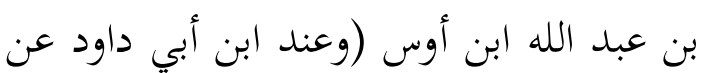

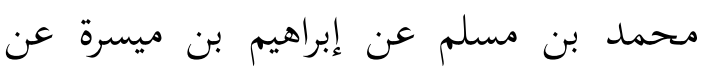
عثمان-محمد هذا سمع عن إبراهيم وعثمان كليهما-ــن عمه عمرو بن أوس عن المغيرة بن شعبة أنه استأذن لرجل على النبي صلى الله عليه وسلم، فقال النبي صلى الله عليه وسلم:

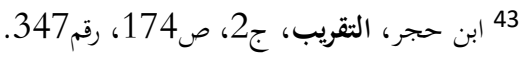

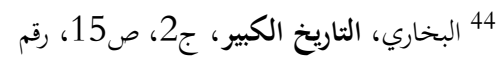

$$
\begin{aligned}
& \text { الترجمة1539(ترجمة أوس بن حذيفة الثقفي). }
\end{aligned}
$$


جبر الأحاديث المرسلة بتعلد طرق أحاديث كتاب فضائل القرآن في مصنف عبد الرزق نموذجا

والبيت الذي لا يقرأ فيه القرآن يقل خيره)). 49

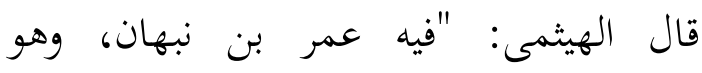
501

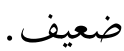

ثانيا: يضيء لأهل السماء كما يضيء النجم لأهل الأرض: أخرجه أبو نعيم موصولا بسنده عن الحسن بن عمارة عن طلحة عن عبد الرحمن بن سابط عن أبيه عن النبي صلى الله عليه وسلم قال: ((إن البيت الذي يذكر الله فيه لينير لأهل السماء كما ينير النجوم لأهل الأرض)). 51 ضعفه ابن حجر، 52 ولكن له له له لهن شاهد أخرجه البيهقي في الشعب قال: نا أبو الحسين محمد بن القاسم الفارسي ثنا أبو بكر بن قريش ثنا الحسن بن سفيان ثنا قتيبة بن سعيد ثنا ابن لهيعة عن أبي الأسود عن عروة عن عائشة رضي الله عنها قالت: قال رسول الله صلى الله عليه وسلم: ((البيت الذي يقرأ فيه القرآن يتراءى لأهل السماء كما تتراءى النجوم

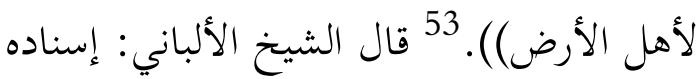
جيد إن ثبت عدالة وحفظ أبي بكر بن قريش، فإني لم أعرفه، وكذلك الراوي عنه. 54 ووجدنا أن أبا بكر هذا هو : أحمد بن يعقوب بن عبد وديد
ويحضره الشياطين. وإن البيت الذي يقرأ فيه القرآن ويثور فيه، يضيء لأهل السماء كما يضيء النجم لأهل الأرض))، قال: ثم قال رسول الله صلى الله عليه وسلم: ((بشر المشائين في الظلم إلى المساجد بنور من الله

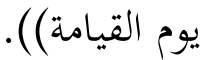

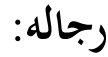

معمر : هو ابن راشد الأزدي، ثقة ثبت تقدم.

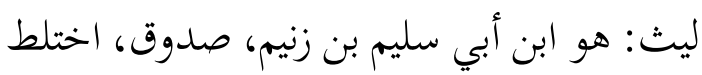

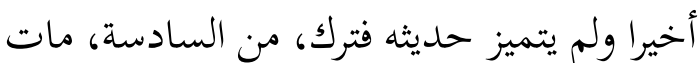
سنة ثمان وأربعين ومائة هـ. 47 عبد الرحمن بن سابط: والصحيح عبد الرحمن بن عبد الله بن سابط، ثقة كثير الإرسال، من الثالثة، مات سنة ثمان عشرة ومائة هـ. 48

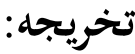
لم تجد الباحثة من أخرجه مركبا هكذا، وإنما

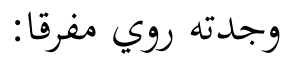
أولا: البيت الذي يقرأ فيه القرآن يكثر خيره: فرواه البزار بسنده عن عمر بن نبهان عن الحسن عن أنس أن النبي صلى الله عليه وسلم قال: ((إن البيت الذي يقرأ فيه القرآن يكثر خيره، 
الحكم على الحديث: الحديث ضعيف بإرساله، ولا نجد له شاهد معتبر ما يجبره، إلا لا لهال الجزء الأخير: ((بشر المشائين))، فإنه حديث متواتر، كما ذكرنا. 8- عبد الرزاق عن عمر بن راشد عن يحي بن أبي كثير رفع الحديث إلى النبي صلى الله عليه وسلم قال: ((سيقرأ القرآن ثناثة: رجل يقرأه ابتغاء مرضاة الله ورجاء ثوابه من الله، فذلك ثوابه على الله، ورجل يقرأه رياء وسمعة ليأكل به في الدنيا، فذلك عليه لا له، ورجل يقرأه فلا يتجاوز قرائته ترقوته أو قال مبقعته)).

رجاله: - (- )

عمر بن راشد: هو ابن شجرة اليمامي، ضعيف، من السابعة. يحي بن أبي كثير: ثقة ثبت، تقدم. تخريجه: رواه ابن نصر عن طريق يحي بن يحي والقاسم

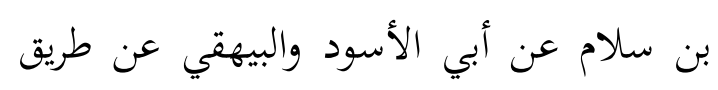

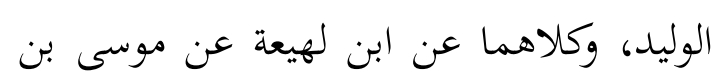
وردان عن أبي الهيثم عن أبي سعيد الخدري أنه

$$
\begin{aligned}
& \text { موسى، 81، ص77، رقم3074، والطبراني، المعجم الكبير، عبد }
\end{aligned}
$$

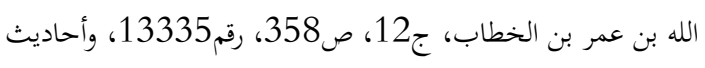

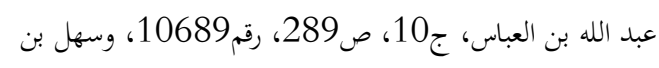

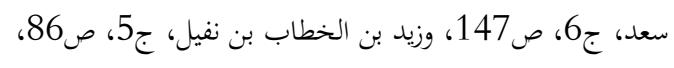

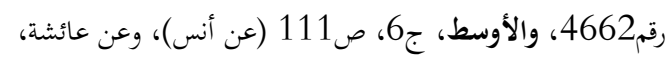

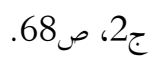

$$
\begin{aligned}
& 58 \text { ابن حجر، التقريب، ج2، ص55، رقم421. }
\end{aligned}
$$

الجبار بن يعاطر بن مصعب بن سعيد بن مسلمة بن عبد الملك بن مروان بن الحكم أبو بكر القرشي الأموي الجرجاني. روى ابن عساكر عن أبي بكر البيهقي: أحمد بن يعقوب كان يعرف بابن بغاطرة القرشي الأموي له أحاديث موضوعة لا أستحل رواية شئ منها. 55 والراوي عنه وهو أبو الحسين محمد بن القاسم الفارسي أحد تلاميذه، كثر ذكره، وذكر روايته عن أحمد بن يعقوب، ولم نظفر بمعرفة مرتبته من الجرح والتعديل. ولكن معرفة حال شيخه كفانا لتضعيف هذا الحديث. ثالثا: ((بشر المشائين إلى المساجد في الظلم يوم القيامة)): فهو حديث متواتر 56 رواه غير واحد من الصحابة، أخرجه أبو داود والترمذي والبيهتي والطبراني عن بريدة والبزار عن أبي موسى وابن ماجه والطبراني عن أنس وأبو يعلى عن أبي سعيد والبيهقي والطبراني عن سهل والطبراني عن ابن عباس وابن عمر وزيد بن حارثة وعائشة ((بشر المشائين في الظلم إلى لى المساجد بنور تام يوم القيامة)). 57

$$
\begin{aligned}
& 55 \text { ابن عساكر، تاريخ دمشق، ج6، ص101، رقم323. }
\end{aligned}
$$

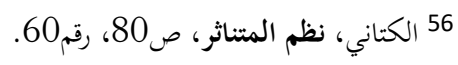

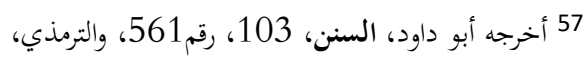

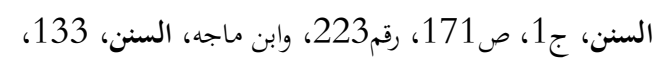

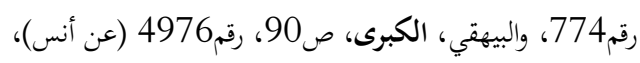

$$
\begin{aligned}
& \text { 4978 (عن بريدة)، وأبو يعلى، المسند، مسند أبي سعيد }
\end{aligned}
$$

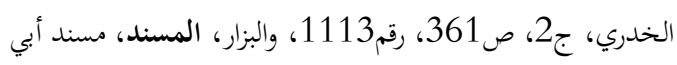


الحكم على الحديث: سند الحديث ضعيف لضعف عمر بن راشد وبإرساله، ويرتقي إلى الحسن لغيره بشاهده.

9- عبد الرزاق عن معمر عن أبي إسحاق عن عمرو بن ميمون الأودي قال: قال رسول الله صلى الله عليه وسلم: ((قل هو الله أحد تعدل

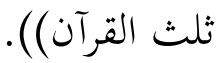

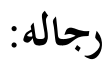
معمر : هو ابن راشد الأزدي، ثقة ثبت، تقدم. أبو إسحاق: هو عمرو بن عبد الله الهمداني ابو إسحاق السبيعي، مكثر ثنة عابد، من الثالثة، مات سنة تسع وعشرين ومائة هـ وقيل قبل ذلك. عمرو بن ميمون الأودي: أبو عبد الله ويقال أبو يحي مخضرم مشهور، ثقة، مات سنة أربع 62 وسبعين هـ

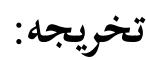
رواه مرسلا النسائي عن زائدة وسفيان عن أبي إسحاق عن عمرو بن ميمون الأودي عن النبي صلى الله عليه وسلم: ((قل هو الله أحد ثلث

\footnotetext{
رقم3416، والحافظ أبو محمد عبد الرحمن بن أبي حاتم الرازي،

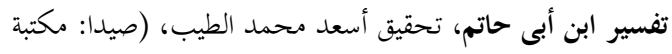

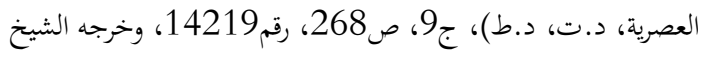

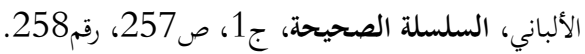

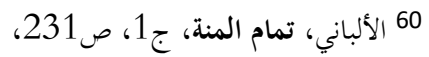

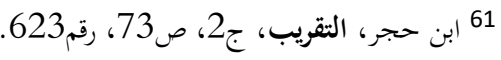

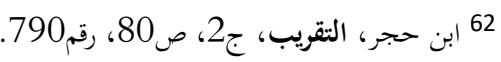

سمع النبي صلى الله عليه وسلم يقول: ((تعلموا القرآن وسلوا الله به الجنة قبل أن يتعلمه قوم يسألون به الدنيا، فإن القرآن يتعلمه ثلاثة: رجل يباهي، ورجل يستأكل به، ورجل يقرأه لله)(). ضعفه الشيخ الألباني سنده من أجل ابن لهيعة، ولكنه كما قال الشيخ لم ينفرد به، حيث روى من طريق آخر، أخرجه البخاري في الخلق وأحمد والحاكم عن عبد الله بن يزيد المقري ثنا حيوة حدثني بشير بن أبي عمرو الخولاني أن الوليد بن قيس التجيبي حدثه أنه سمع أبا سعيد الخدري يقول سمعت رسول الله صلى الله عليه وسلم يقول: ((يخلف قوم من بعد ستين سنة أضاعوا الصلاة واتبعوا الشهوات فسوف يلقون غيا، ثم يكون خلف يقرأون القرآن لا يعدوا تراقيهم، ويقرأ القرآن ثلاثة: مؤمن، ومنافق، وفاجر)). هذا الحديث صححه الحاكم، وحسنه الشيخ الألباني، لأن الوليد لم يوثقه غير ابن حبان والعجلي، 59 وقد اعتبرهما الشيخ من المتساهلين.

$$
\begin{aligned}
& 59 \text { أخرجه محمد بن نصر المروزي، مختصر قيام الليل } \\
& \text { وقيام رمضان وكتاب الوتر، (فيصل آباد: حديث أكاديمي، ط1 1988، }
\end{aligned}
$$

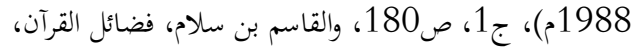

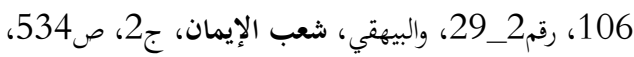

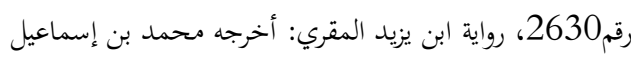

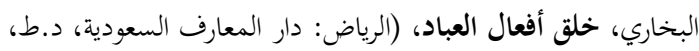

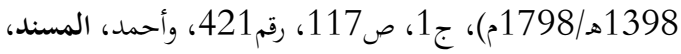

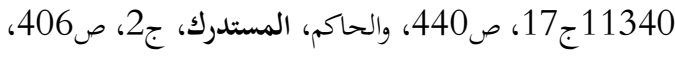


القرآن)). ورواه الترمذي وابن ماجه عن ميمون رجل: مبهم.

الحسن: هو البصري، ثقة، فاضل، تقدم.

$$
\text { تخريجه: }
$$

له شاهد أخرجه الطبراني وابن عدي وأبو نعيم

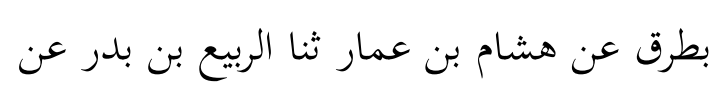

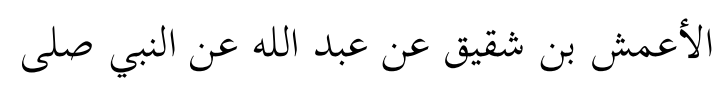

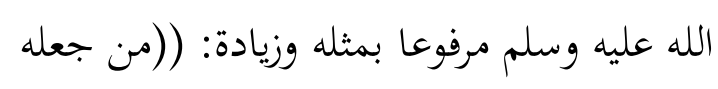

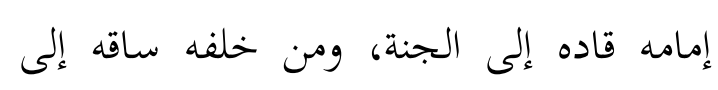
النار)). 64 وقال أبو نعيم: "غريب من الجنة ومن حديث الأعمش، تفرد به عنه الربيع،" وقال الشيخ الشيخ الألباني: "وهو متروك، وقد خولف." "65 ولكن

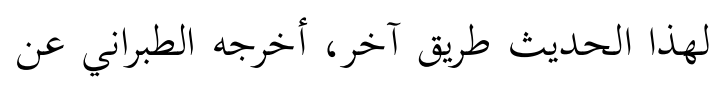
إسحاق بن إبراهيم الدبري عن عبد الرزاق عن الثوري عن أبي إسحاق وغيره عن عبد الرحمن بن يزيد عن عبد الله بن مسعود موقوفا بنحوه. 66

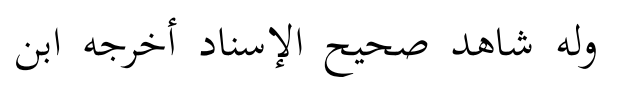

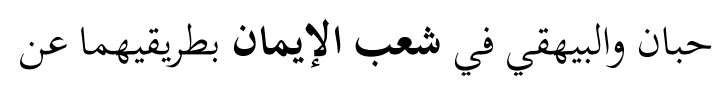

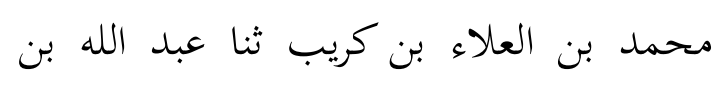
الأجلح عن الأعمش عن أبي سفيان عن جابر عن النبي صلى الله عليه وسلم بمثله. 67

$$
\begin{aligned}
& \text { بدر، ص30، وأبو نعيم، الحلية، ج4، ص115، رقم4954 (ترجمة }
\end{aligned}
$$

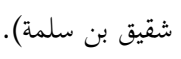

$$
\begin{aligned}
& 65 \text { الألباني، السلسلة الصحيحة، 5، ص18، رقم2019. }
\end{aligned}
$$

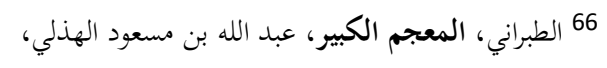

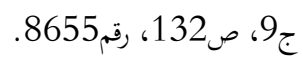

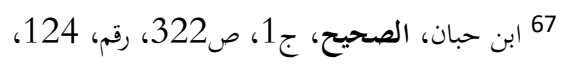

$$
\begin{aligned}
& \text { شعب الإيمان، ج2، ص351، رقم2010، جان. }
\end{aligned}
$$

موصولا عن عمرو بن ميمون عن عبد الرحمن

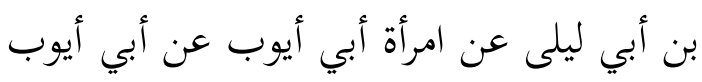

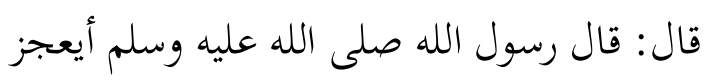
أحدكم أن يقرأ في ليلة ثلث القرآن؟ من قرأ الله الواحد الصمد فقد قرأ ثلث القرآن)). 63 وهذا حديث صحيح أخرجه أصحاب الكتب الستة وغيرهم بطرق كثيرة جدا عن أبي الدرداء وأبي سعيد وأبي هريرة وأبي مسعود وقتادة وابن عباس وابن عمر والنعمان بأحد السياق الثلاثة المذكورة أو بنحوها. الحكم على الحديث: رجال الإسناد ثقات، والحديث ضعيف لإرساله، ويرتقي إلى الحسن لغيره بموصوله وشواهده.

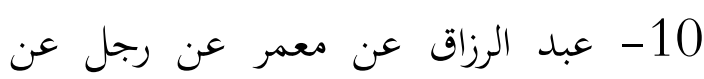
الحسن قال: قال رسول الله صلى الله عليه وسلم: إن هذا القرآن شافع ومشفع وماحل ومصدق)(). رجاله: - وم: معمر: هو ابن راشد الأزدي، ثقة ثبت، تقدم.

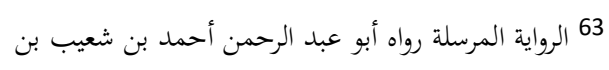

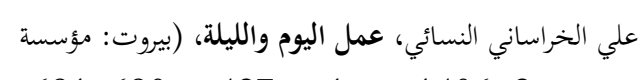

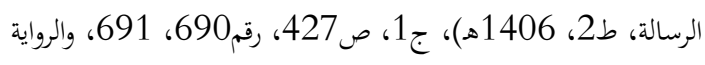

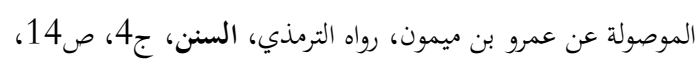

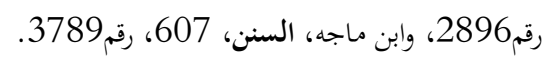

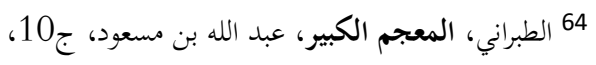

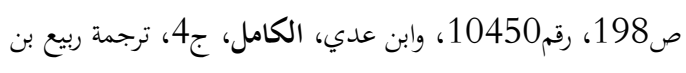


جبر الأحاديث المرسلة بتعلد طرق أحاديث كتاب فضائل القرآن في مصنف عبد الرزاق نموذجا

معظم مراسيل المصنف رويت موصولة،

أو مرسلة صحيحة، أو لها شواهد ما يعضدها

ويجبرها فيرتقي إلى الحسن لغيره، وقليل منها ما يبقى ضعيفا. ووجدت الباحثة خلال تخريج عشر حديثا من الكتب الثلاثة المذكورة، أن خمسة حديثا أو (50\%) بالنسبة المائوية، يرتقي إلى الحسن لغيره، وأخرى الخمسة عشر لا ينجبر لعدم وجود ما يعضده من شواهد أو الو متابعات أقوى في الحكم.
قال الشيخ الألباني: "وإسناده جيد، رجاله تقنات. " الحكم على الحديث: إسناد الحديث ضعيف لأن فيه رجل مبهم، والحديث مرسل، ويرتقي إلى الحسن لغيره بشاهده. الخاتمة صح قول جمهور المحدثين الذين يرون أن المرسل يكون مقبولا إذا روي من طريق آخر

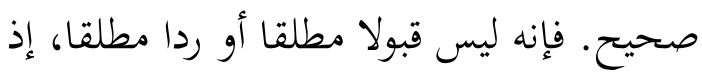
وجدت الباحثة من المراسيل ما رويت متواترة

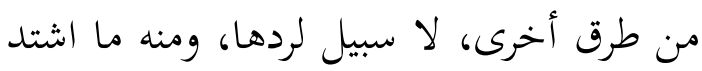

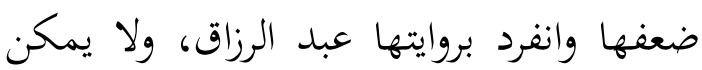

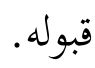

ووجدنا أن علم التخريج علم جليل كثير الفائدة، يصفي به صحيح أحاديث رسول الله صلى الله عليه وسلم من عليلها، ويطهرها مما دخل عليها من أكاذيب الوضاعين على النبي صلى الله عليه وسلم كما أن الإعتبار أو مقارنة بين طرق حديث خلال التخريج كثير ما يزيل الإبهام، ويبين السقط، وييرز الزيادة والنقصان والتحريف والتصحيف والعلة والخلاف والإنكار

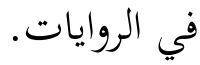


جبر الأحاديث المرسلة بتعدد طرق أحاديث كتاب فضائل القرآن في مصنف عبد الززق نموذجا

\section{المصادر والمراجع}

ابن الجوزي، جمال الدين أبو الفرج الرحمن بن علي بن محمد الضعفاء والمتروكين، تحقيق أبو الفداء

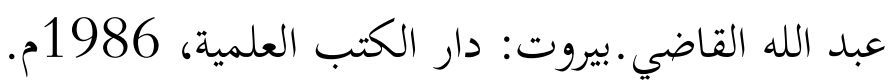
الألباني، محمد ناصر الدين الحاج نوح الألباني، سلسلة الأحاديث الصحيحة. الرياض: مكتبة المعارف، 1979

الأصفهاني، أبو نعيم أحمد بن عبد الله الشافعي، حلية الأولياء وطبقات الأصفياء. بيروت: دار الكتب العلمية، 2002م.

البخاري، أبو عبدالله محمد بن إسماعيل بن إبراهيم بن المغيرة، التاريخ الكبير، تحقيق مصطفى عبد

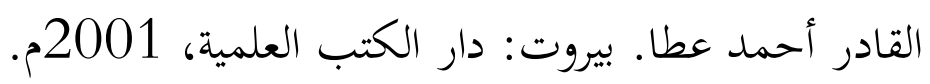

البُستي، أبو حاتم محمد بن حبان بن أحمد بن معاذ بن معبد. معرفة الثقات، تحقيق عبد العليم عبد

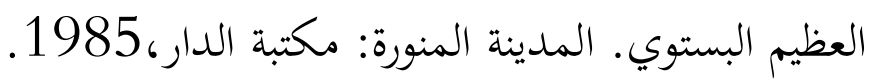
البيهقي، أبو بكر أحمد بن الحسين بن علي. السنن الكبرى، تحقيق عبد القادر عطا. بيروت: دار

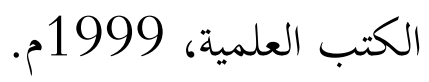

التبريزي، محمد بن عبد الله الخطيب العمري مشكاة المصابيح، تحقيق محمد ناصر الدين الألباني، بيروت: المكتب الإسلامي 1985م.

الجرجاني، أبو أحمد عبد الله بن عدي، الكامل في ضعفاء الرجال، تحقيق وتعليق الشيخ عادل أحمد عبد الموجود والشيخ علي محمد معوّض. بيروت: دار الكتب العلمية، 1997م. الحاكم ، الإمام الحافظ أبو عبد الله محمد بن عبد الله الحاكم النيسابوري ، المستدرك على لهي الصحيحين، تحقيق مصطفى عبد القادر عطا. بيروت: دار الكتب العلمية 1999 . الخير آبادي، محمد أبو الليث " مصنف الإمام عبد الرزاق الصنعاني: مكانته ومنهجه وفوائده"، مجلة الإسلام في آسيا، الجزء الثالث، العدد2، ديسمبر. الخير آبادي، علوم الحديث أصيلها ومعاصرها. كوالا لمبور: دار الشاكر، 2005. 
جبر الأحاديث المرسلة بتعدد طرق أحاديث كتاب فضائل القرآن في مصنف عبد الززق نموذجا

الدارقطني، الإمام الحافظ علي بن عمر. سنن الدارقطني. بيروت: دار الكتب العلمية،(200م. الدهلوي، أحمد شاه ولي الله بن عبد الرحيم حجة الله البالغة. بيروت: دار الكتب العلمية، د.

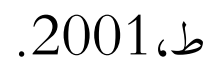

الذهبي، أبو عبد الله محمد بن أحمد بن عثمان. ميزان الاعتدال في نقد الرجال تحقيق شعيب الأرنؤوط.

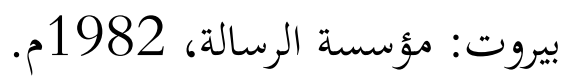

الرازي، والحافظ أبو محمد عبد الرحمن بن أبي حاتم، تفسير ابن أبى حاتم، تحقيق أسعد محمد الطيب. صيدا: مكتبة العصرية، د.ت، د.ط.

الزركشي، بدر الدين أبو عبد الله محمد بن جمال الدين عبد الله بن بهادر، النكت على مقدمة ابن

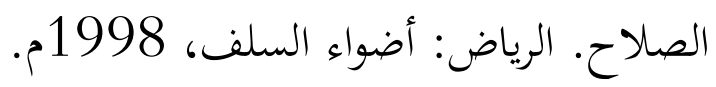

السجستاني، أبو داود، سليمان بن الأشعث، سنن أبي داود. بيروت: دار الكتب العلمية، 2001م. السنيكي، زين الدين أبو يحي زكريا بن محمد زكريا، فتح الباقي على ألفية العراقي مع التبصرة والتذكرة.

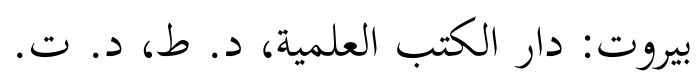

السيوطي، عبد الرحمن بن أبي بكر جلال الدين تدريب الراوي في شرح تقريب النووي. القاهرة: دار

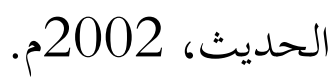

السيوطي، الدر المنثور في التأويل بالمأثور. بيروت: دار الكتب العلمية، 1421هـ. صادق، اللواء حسن، جزور الفتنة في الفرق الإسلامية، القاهرة: مكتبة المدبولي. الطحان، محمود، تيسير مصطلح الحديث.الرياض: مكتبة المعارف للنشر والتوزيع، 1996. العراقي، محمد بن الحسين الحسيني، شرح ألفية العراقي المسماة بالتبصرة والتذكرة. بيروت: دار الكتب

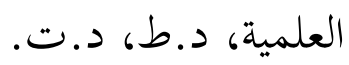

العراقي، التقييد والإيضاح شرح مقدمة ابن الصلاح، وضع حواشيه محمد عبد الله شاهين. بيروت: دار

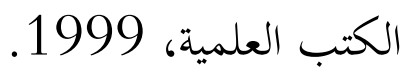

العسقلاني، أبو الفضل أحمد بن علي بن محمد بن علي بن حجر، نزهة النظر بشرح نخبة الفكر في

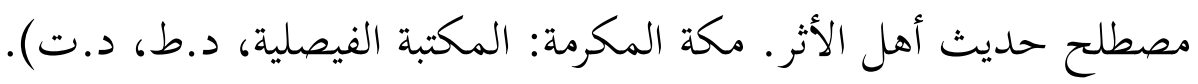
ل 
، فتح الباري شرح صحيح البخاري. بيروت: دار المعرفة، 1379. ، هدي الساري مقدمة فتح الباري. بيروت: دار الكتب العلمية، 2003م.

، تقريب التهذيب، حققه وعلقه وقدم حواشيه عبد الوهاب عبد اللطيف، د.ط. 1975م.

، الدراية في تخريج أحاديث الهداية، تحقيق السيد عبد الله هاشم اليماني المدني، بيروت:

$$
\text { دار المعرفة، د.ت، د.ط. }
$$

، الإصابة في تمييز الصحابة. بيروت: دار الكتب العلمية، ـ (2002م).

، التلخيص الحبير في تخريج أحاديث الرافعي الكبير، تحقيق الشيخ عادل أحمد

$$
\text { محمود. بيروت: دار الكتب العلمية، 1998م. }
$$

، تعجيل المنفعة بزوائد رجال الأئمة الأربعة، تحقيق د. إكرام الله إمداد الحق. بيروت:

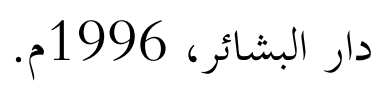

$$
\text { ، تهذيب التهذيب. بيروت: دار التراث العربي 1993م. }
$$

، الدراية في تخريج أحاديث الهداية، تحقيق السيد عبد الله هاشم اليماني المدني.

$$
\text { بيروت:دار المعرفة، د. ط. }
$$

القزويني. ، الحافظ أبو عبد الله محمد بن يزيد بن ماجه، سنن ابن ماجه بيروت: دار الكتب

$$
\text { العلمية، } 2002 \text { ونيني }
$$

النسائي، أبو عبد الرحمن أحمد بن شعيب بن علي الخراساني. السنن الكبرى، أشرف على تحقيقه

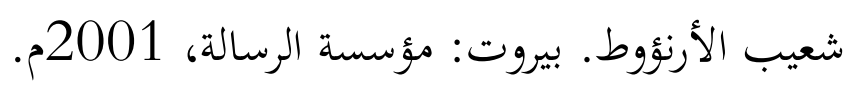

$$
\text { ، عمل اليوم والليلة. بيروت: مؤسسة الرسالة، د.س. }
$$

النيسابوري، أبو بكر محمد بن إسحاق بن خزيمة صحيح ابن خزيمة، تحقيق محمد مصطفى الأعظمي.

$$
\text { بيروت: المكتب الإسلامي، } 1970 .
$$


جبر الأحاديث المرسلة بتعلد طرق أحاديث كتاب فضائل القرآن في مصنف عبد الرزاق نموذجا

المروزي، محمد بن نصر، مختصر قيام الليل وقيام رمضان وكتاب الوتر.فيصل آباد: حديث أكاديمي،

1988

الهروي القاري، علي بن سلطان محمد نور الدين الملا. مرقاة المفاتيح شرح مشكاة المصابيح. بيروت:

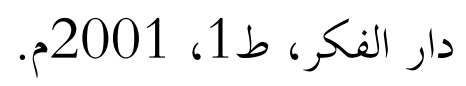

الهيثمي، الحافظ نور الدين علي بن أبي بكر بن سليمان المصري. مجمع الزوائد ومنبع الفوائد، تحقيق

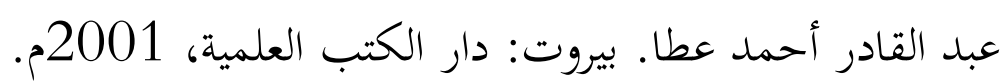

